\title{
Przedsięwzięcia materiałowe i konstrukcyjne zwiększające bezpieczeństwo pojazdów szynowych przed skutkami zderzeń
}

\begin{abstract}
$W$ artykule przedstawiono środki konstrukcyjne $i$ materiałowe zwiększajace pasywne bezpieczeństwo pojazdów szynowych przed skutkami zderzenia. Jak wynika z nowoczesnych trendów rozwojowych w pojazdach szynowych, coraz częściej stosuje sie specjalne elementy zderzno-pochtaniajace oraz dostosowuje sie konstrukcje pojazdu do przejęcia coraz większej energii zderzenia. W opracowaniu przedstawiono również inne środki konstrukcyjne majace na celu zwiększenie pasywnego bezpieczeństwa pojazdów szynowych.

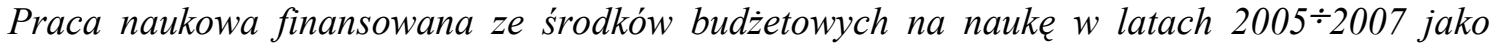
projekt badawczy pt. „, Teoretyczne i techniczne możliwości ksztaltowania stref zgniotu ustrojów nośnych pojazdów szynowych."
\end{abstract}

\section{Wstęp}

W wyniku wzrostu roli „pasywnego bezpieczeństwa” pojazdów szynowych konstruktorzy i producenci są zmuszeni do oferowania nowoczesnych pojazdów szynowych, których konstrukcje są odporne na nadzwyczajne zderzenia. Pasywne bezpieczeństwo pojazdów szynowych obejmuje również konstrukcje już eksploatowane jak np. wagony-cysterny, co wynika $z$ wymagań postawionych elementom zderznopochłaniającym (tzw. crashelemente) wg karty UIC 573 [15]. Nowoczesne konstrukcje są wytwarzane przy stałym nacisku na producentów, dotyczącym obniżenia ceny produktu finalnego. Oferowane pojazdy muszą więc posiadać taką konstrukcję, której koszty eksploatacji, wynikające z napraw oraz przeglądów okresowych, byłyby utrzymane na możliwie najniższym poziomie. Zasada ta dotyczy również elementów zderzno-pochłaniających oraz wszystkich innych przedsięwzięć konstrukcyjnych, które należy zastosować, aby spełnić wymagania pasywnego bezpieczeństwa pojazdów szynowych. Oznacza to „ewolucyjny” rozwój pojazdów szynowych, zwłaszcza w zakresie wagonów towarowych, gdzie rola zamienności części, produkcji wielkoseryjnej oraz obowiązujących przepisów unifikacyjnych jest największa [8,10,13 i 25]. Konstrukcja elementów zderzno-pochłaniajacych jest jednak zawsze uzależniona od specyfiki pojazdów szynowych. W przypadku wagonów towarowych wpływ obowiązujących przepisów dotyczących standaryzacji, unifikacji oraz zamienności na konstrukcję elementów zderzno-pochłaniających jest największy. W przypadku wagonów osobowych, a zwłaszcza wagonów metra i zespołów trakcyjnych przystosowanych do wysokich prędkości ( $\mathrm{v} \geq 250 \mathrm{~km} / \mathrm{h}$ zgodnie z kartą UIC 660 [16]), elementy zderzno-pochłaniające oraz inne przedsięwzięcia konstrukcyjne zabezpieczające konstrukcję przed skutkami zderzeń moga być bardziej urozmaicone i przyjmować nietypowy kształt. W przypadku wagonów towarowych okresy międzynaprawcze są najdłuższe $\mathrm{w}$ porównaniu ze wszystkimi pojazdami występującymi w technice kolejowej. Istotne jest również sprawdzenie wymagań, stawianych nowoczesnym konstrukcjom pojazdów szynowych w zakresie zabezpieczenia przed skutkami zderzeń i w tym celu opracowuje się odpowiednie metodyki badawcze $\lceil 3$ i 6$\rceil$.

\section{Przedsięwzięcia w zakresie nowych materiałów 2.1. Nowe stale na elementy konstrukcji nośnych pojazdów}

Energia kinetyczna poruszającego się pojazdu $\mathrm{E}_{\mathrm{K}}$ podczas zderzenia dzieli się na energię odkształcenia sprężystego $E_{S P R}$ oraz energię odkształcenia trwałego $E_{T R W}$. Bilans energetyczny zderzenia można zapisać następująco:

$$
\mathrm{E}_{\mathrm{K}}=\mathrm{E}_{\mathrm{SPR}}+\mathrm{E}_{\mathrm{TRW}}
$$

Podstawowym parametrem, który pozwala uniknąć odkształceń trwałych, względnie utrzymać je w określonym zakresie, jest granica plastyczności użytego materiału na konstrukcje.

Takim wskaźnikiem charakteryzującym konstrukcję jest tzw. uogólniony wskaźnik wytrzymałościowy $W_{U}$ $O G$, który charakteryzuje zdolność materiału do przejęcia największych obciążeń przy najmniejszych odkształceniach i najmniejszej masie elementu konstrukcyjnego i wyraża się wzorem:

$$
W_{U O G}=\frac{R_{0,2} \cdot E}{\rho \cdot g}
$$

gdzie:

$\mathrm{R}_{0,2}$-granica plastyczności zastosowanego materiału [MPa] 
E- moduł Younga w [MPa]

$\rho$ - masa właściwa $\left[\mathrm{kg} / \mathrm{m}^{3}\right]$

g- przyspieszenie ziemskie $\left\lceil\mathrm{m} / \mathrm{s}^{2}\right\rceil$.

Konstrukcje wagonów towarowych oraz większości wagonów pasażerskich są wykonane ze stali i przeniesienie maksymalnej siły ściskającej, wynikającej ze zderzenia, jest zależne między innymi od granicy plastyczności stali $R_{0,2}$. W związku z tym na nowoczesne konstrukcje należy użyć wysokowytrzymałych stali, posiadających wysoką granicę wytrzymałości na rozciaganie $R_{m}$ oraz wysoką granice plastyczności $R_{0.2}$. Obecnie do wysokowytrzymałych stali, mających powszechne zastosowanie, można zaliczyć:
- $\quad$ stal S355 J2 wg normy PN-EN 10 025-2 [18], posiadającą granicę plastyczności $\mathrm{R}_{0.2}=355$ MPa oraz granicę wytrzymałości na rozciąganie $\mathrm{R}_{\mathrm{m}}=490 \div 630 \mathrm{MPa}$; często używany jest gatunek tej stali S355J2G1WC+N np. przez fabrykę Siemens SGP „Verkehrstechnik” na konstrukcje współczesnych układów biegowych [4]

- nowe wysokowytrzymałe stale typu Domex charakteryzujące się wysoką odpornością na czynniki atmosferyczne oraz korozję; ich rozwój promuje szwedzka firma SSAB ( Swedish Steel GmbH ).

Ich skład chemiczny oraz własności mechaniczne są przedstawione w tabelach 1 i 2 ¡23 i 24$\rceil.$

Skład chemiczny stali typu „Domex” formowanych na zimno wg [23]

Tabela 1

\begin{tabular}{|l|c|c|c|c|c|c|c|}
\hline $\begin{array}{l}\text { Gatunek } \\
\text { stali }\end{array}$ & $\mathrm{C}_{\max }[\%]$ & $\mathrm{Mn}_{\max }[\%]$ & $\mathrm{Si}_{\max }[\%]$ & $\mathrm{P}_{\max }[\%]$ & $\mathrm{S}_{\max }[\%]$ & $\mathrm{Al}_{\min }[\%]$ & $\begin{array}{c}\text { Inne } \\
\text { pierwiastki }\end{array}$ \\
\hline $\begin{array}{l}\text { Domex } \\
315 \mathrm{MC}\end{array}$ & 0.10 & 1.30 & $0.03^{1)}$ & 0,025 & 0,010 & 0,015 & $*)$ \\
\hline $\begin{array}{l}\text { Domex } \\
355 \mathrm{MC}\end{array}$ & 0.10 & 1.30 & $0.03^{1)}$ & 0.025 & 0,010 & 0,015 & $*)$ \\
\hline $\begin{array}{l}\text { Domex } \\
420 \mathrm{MC}\end{array}$ & 0.10 & 1.50 & $0.03^{2)}$ & 0.025 & 0,010 & 0,015 & $*)$ \\
\hline $\begin{array}{l}\text { Domex } \\
460 \mathrm{MC}\end{array}$ & 0.10 & 1.50 & $0.30^{2)}$ & 0.025 & 0,010 & 0,015 & $*)$ \\
\hline $\begin{array}{l}\text { Domex } \\
500 \mathrm{MC}\end{array}$ & 0.10 & 1.50 & $0.30^{2)}$ & 0.025 & 0,010 & 0,015 & $*)$ \\
\hline $\begin{array}{l}\text { Domex } \\
550 \mathrm{MC}\end{array}$ & 0.12 & 1.60 & $0.30^{2)}$ & 0.025 & 0,010 & 0,015 & $*)$ \\
\hline $\begin{array}{l}\text { Domex } \\
600 \mathrm{MC}\end{array}$ & 0.12 & 1.80 & 0.30 & 0.025 & 0,010 & 0,015 & $* *)$ \\
\hline $\begin{array}{l}\text { Domex } \\
650 \mathrm{MC}\end{array}$ & 0.12 & 2.00 & 0.30 & 0.025 & 0,010 & 0,015 & $* *)$ \\
\hline $\begin{array}{l}\text { Domex } \\
700 \mathrm{MC}\end{array}$ & 0.12 & 2.10 & 0.30 & 0.025 & 0,010 & 0,015 & $* *)$ \\
\hline
\end{tabular}

1) W przypadku galwanizowania na gorqco grubość powłoki cynkowej Zn wynosi $50 \div 80 \mu m$.

2) Taka sama grubość powłoki cynkowej jest stosowana przy zawartości 0,03\% krzemu. Jeśli stal nie podlega procesowi galwanizacji i stal z maksymalnq zawartościq Si wynoszqca 0.03\% nie jest możliwa do stosowania, to wówczas zawartość krzemu musi wynosić powyżej 0,02\%. Jeśli materiat jest galwanizowany na gorqco, to należy to wyspecyfikować zgodnie z przepisami.

*) Nb-0.09\% max., V-0.20\%max., Ti- 0,15\% max., suma zawartości pierwiastków Nb, Vi Ti nie może przekraczać $0,22 \%$.

**) dla tych stali zagwarantowana jest taka sama zawartość pierwiastków jak $w$ *) $i$ ponadto Mo0,50\% max., B- 0,005\% max. 
Wlasności wytrzymałościowe stali typu „Domex” formowanych na zimno wg [23]

Tabela 2

\begin{tabular}{|c|c|c|c|c|c|c|c|}
\hline \multirow[t]{2}{*}{$\begin{array}{l}\text { Gatunek } \\
\text { stali }\end{array}$} & \multirow{2}{*}{$\begin{array}{c}\text { Granica } \\
\text { plastycz- } \\
\text { ności } \\
\mathrm{R}_{0.2}[\mathrm{MPa}]\end{array}$} & \multirow{2}{*}{$\begin{array}{c}\text { Granica } \\
\text { wytrzymałości } \\
\text { na rozciąganie } \\
\mathrm{R}_{\text {mmin-max }}[\mathrm{MPa}]\end{array}$} & \multicolumn{2}{|c|}{$\begin{array}{c}\text { Minimalne } \\
\text { wydłużenie } \\
\text { względne w [ \%] } \\
\text { dla blachy o } \\
\text { grubości t [mm] }\end{array}$} & \multicolumn{3}{|c|}{$\begin{array}{l}\text { Praktyczne zastosowanie. } \\
\text { Minimalny wymagany } \\
\text { promień gięcia }\left(\leq 90^{\circ}\right) \text { dla } \\
\text { blachy o minimalnej grubości } \\
\text { t }[\mathrm{mm}]\end{array}$} \\
\hline & & & $\begin{array}{r}A_{80} \\
t<3 \\
\end{array}$ & $\begin{array}{l}A_{5} \\
t \geq 3\end{array}$ & $\mathrm{t} \leq 3$ & $3<t<6$ & t? 6 \\
\hline $\begin{array}{l}\text { Domex } \\
315 \mathrm{MC}\end{array}$ & 315 & $390 \div 510$ & 20 & 24 & $0,2 \mathrm{t}$ & $0,3 \mathrm{t}$ & $0,6 \mathrm{t}$ \\
\hline $\begin{array}{l}\text { Domex } \\
355 \mathrm{MC} \\
\end{array}$ & 355 & $430 \div 550$ & 19 & 23 & $0,2 \mathrm{t}$ & $0,3 \mathrm{t}$ & $0,7 \mathrm{t}$ \\
\hline $\begin{array}{l}\text { Domex } \\
420 \mathrm{MC}\end{array}$ & 420 & $480 \div 620$ & 16 & 20 & $0,4 \mathrm{t}$ & $0,5 \mathrm{t}$ & $0,9 \mathrm{t}$ \\
\hline $\begin{array}{l}\text { Domex } \\
460 \mathrm{MC}\end{array}$ & 460 & $520 \div 670$ & 15 & 19 & $0,5 \mathrm{t}$ & $0,7 \mathrm{t}$ & $1,1 \mathrm{t}$ \\
\hline $\begin{array}{l}\text { Domex } \\
500 \mathrm{MC}\end{array}$ & 500 & $550 \div 700$ & 14 & 18 & $0,6 \mathrm{t}$ & $0,8 \mathrm{t}$ & $1,2 \mathrm{t}$ \\
\hline $\begin{array}{l}\text { Domex } \\
550 \mathrm{MC}\end{array}$ & 550 & $600 \div 760$ & 14 & 17 & $0,6 \mathrm{t}$ & $1,0 \mathrm{t}$ & $1,3 \mathrm{t}$ \\
\hline $\begin{array}{l}\text { Domex } \\
600 \mathrm{MC}\end{array}$ & 600 & $650 \div 820$ & 13 & 16 & $0,7 \mathrm{t}$ & $1,1 \mathrm{t}$ & $1,4 \mathrm{t}$ \\
\hline $\begin{array}{l}\text { Domex } \\
650 \mathrm{MC}\end{array}$ & $650^{1)}$ & $700 \div 880$ & 12 & 14 & $0,8 \mathrm{t}$ & $1,2 \mathrm{t}$ & $1,5 \mathrm{t}$ \\
\hline $\begin{array}{l}\text { Domex } \\
700 \mathrm{MC}\end{array}$ & $700^{1)}$ & $750 \div 950$ & 10 & 12 & $0,8 \mathrm{t}$ & $1,2 \mathrm{t}$ & $1,6 \mathrm{t}$ \\
\hline
\end{tabular}

Wymienione stale typu Domex MC można podzielić na:

- stale o wysokiej wytrzymałości, Domex HS (high steels): stale typu Domex 315MC, $355 \mathrm{MC}$ i $420 \mathrm{MC}$

- stale o ekstra wysokiej wytrzymałości typu Domex EHS (extra high steels): stale typu Domex 460MC do 700MC.

Analizując skład chemiczny można wyciagnąc wniosek, że proponowane stale posiadają niską zawartość węgla, natomiast wysokie własności wytrzymałościowe osiaga się poprzez zastosowanie pierwiastków stopowych. Niska zawartość węgla poprawia spawalność, lecz wysoka zawartość pierwiastków stopowych pogarsza ją, co można uzasadnić stosując pojęcie tzw. cieplnego równoważnika węgla, wyrażającego się wzorem wg [2]:

$$
C_{E}[\%]=C+\frac{M n}{6}+\frac{C r+M o+V}{5}+\frac{C u+N i}{15}
$$

Dla stali Domex HS cieplny równoważnik węgla nie przekracza wartości $0,2 \%$, dla stali Domex EHS wynosi przeciętnie ok. $0,3 \%$ a maksymalnie nie przekracza $0,4 \%$ ( taka sama wartość jak dla stali S355J2).

Zgodnie z [23 i 24] stale Domex HS oraz Domex EHS można zaliczyć do dobrze spawalnych kierując się zasadą, że jeśli:
- $\quad \mathrm{C}_{\mathrm{E}}<0,42 \%$-stal jest dobrze spawalna

- $0,42 \% \leq \mathrm{C}_{\mathrm{E}}<0,6 \%$-stal jest spawalna pod pewnymi warunkami (skład chemiczny i grubość blach)

- $\quad \mathrm{C}_{\mathrm{E}} \geq 0,6 \%$-stal jest trudnospawalna.

Wg [23 i 24] stale wysokowytrzymałe typu Domex HS oraz Domex EHS posiadaja dobra spawalność wszystkimi metodami spawalniczymi:

- w osłonie gazów obojętnych ( MAG, MIG, TIG)

- ręcznie (MMA)

- łukiem krytym ( SAW-submerged arc welding).

Można więc wyciągnąć wniosek, że stale typu Domex mogą być stosowane na konstrukcję nośną pojazdów szynowych, która będzie spełniała warunek przejmowania większej energii podczas zderzeń nadzwyczajnych, przyjmując dwa możliwe warianty skutków zderzeń:

- konstrukcja stalowa po zderzeniu nie wykazuje żadnych odkształceń trwałych, jak również granica plastyczności $\mathrm{R}_{0,2}$ nie zostaje przekroczona

- konstrukcja stalowa po zderzeniu wykazuje odkształcenia trwałe, jednak nie doszło do utraty jej funkcji, ani też nośności konstrukcji. 
Jednym z parametrów charakteryzujących materiał do przejmowania energii zderzenia jest energia sprężysta właściwa $\Phi$, którą określa się ze wzoru:

$$
\Phi=\frac{1}{2} \cdot \frac{\sigma^{2}}{E}
$$

albo inaczej:

$$
\Phi=\frac{1}{2} \cdot E \cdot \varepsilon^{2}
$$

gdzie:

$\sigma$ - naprężenie rozciaggające [MPa],

$\varepsilon$ - odkształcenie względne [-],

E- moduł Younga [MPa].

Po wyprowadzeniu różnych zależności na energię sprężystą $\Phi$ najbardziej przydatny do dalszych analiz jest wzór (4). Po uwzględnieniu, że $\sigma=\mathrm{R}_{0,2}$ wzór (4) przyjmuje postać:

$$
\Phi=\frac{1}{2} \cdot \frac{R_{0,2}^{2}}{E}
$$

gdzie:

$\mathrm{R}_{0,2^{-}}$granica plastyczności odpowiadająca trwałemu wydłużeniu wynoszącemu $0,2 \%$ długości pierwotnej $1_{0}$

W tabeli 3 dokonano zestawienia energii sprężystej $\Phi$, którą mogą przejąć elementy konstrukcyjne w postaci prętów, wykonanych $\mathrm{z}$ różnych gatunków stali typu Domex bez przekroczenia granicy plastyczności oraz odkształceń trwałych, dla $\rho=7860 \mathrm{~kg} / \mathrm{m}^{3}$ i $\mathrm{E}=2,06 \cdot 10^{5}$ MPa.
Energia sprężysta właściwa $\Phi$ jest energią jednostkową przypadającą na jednostkę objętości pręta stalowego o powierzchni $\mathrm{F}$ i długości l. W związku z tym, że $1 \mathrm{MPa}=10^{6} \mathrm{~N} / \mathrm{mm}^{2}$ oraz $1 \mathrm{~J}=1 \mathrm{~N} \cdot \mathrm{m}$ można zapisać następującą zależność:

$$
\frac{J}{\mathrm{~mm}^{3}}=\frac{\mathrm{N} \cdot \mathrm{m}}{\mathrm{mm}^{3}}=\frac{10^{3} \mathrm{~N} \cdot \mathrm{mm}}{\mathrm{mm}^{3}}=10^{3} \frac{\mathrm{N}}{\mathrm{mm}^{2}}
$$

Samo zastosowanie stali o wysokich własnościach wytrzymałościowych nie powoduje jeszcze zabezpieczenia konstrukcji przed skutkami zderzeń. Ważne jest również osiągnięcie optymalnej sztywności, której powiększenie można osiągnąć przez zastosowanie następujących zabiegów konstrukcyjnych:

- dążenie do wyeliminowania zginania jako obciążenia niekorzystnego ze względu na sztywność i wytrzymałość i zastapienie go ściskaniem i rozciąganiem

- w przypadku elementów pracujących na zginanie-racjonalne rozstawienie podpór, eliminowanie rodzajów obciążenia niekorzystnego ze względu na sztywność

- w przypadku elementów skrzynkowychstosowanie kształtów skorupowych, sklepionych, kulistych, eliptycznych itd.

Kolejnym parametrem wytrzymałościowym, który należy rozważyć przy określaniu kryteriów, jakie musi spełnić nowoczesna konstrukcja wykazująca się dużą odpornością na uderzenia jest udarność. Jak wynika $\mathrm{z}$ informacji przedstawionych w materiałach reklamowych [ 23 i 24]

\begin{tabular}{|c|c|c|c|c|c|c|c|c|c|c|}
\hline L.p & Cechy & $\begin{array}{l}\text { Domex } \\
315 \mathrm{MC}\end{array}$ & $\begin{array}{l}\text { Domex } \\
355 \mathrm{MC}\end{array}$ & $\begin{array}{l}\text { Domex } \\
420 \mathrm{MC}\end{array}$ & $\begin{array}{l}\text { Domex } \\
460 \mathrm{MC}\end{array}$ & $\begin{array}{l}\text { Domex } \\
500 \mathrm{MC}\end{array}$ & $\begin{array}{l}\text { Domex } \\
550 \mathrm{MC}\end{array}$ & $\begin{array}{l}\text { Domex } \\
600 \mathrm{MC}\end{array}$ & $\begin{array}{l}\text { Domex } \\
650 \mathrm{MC}\end{array}$ & $\begin{array}{l}\text { Domex } \\
700 \mathrm{MC}\end{array}$ \\
\hline 1 & $\begin{array}{c}\text { granica } \\
\text { plastyczności } \\
\mathrm{R}_{\mathrm{emin}}[\mathrm{MPa}]\end{array}$ & 315 & 355 & 420 & 460 & 500 & 550 & 600 & $650^{1)}$ & $700^{1)}$ \\
\hline 2 & $\begin{array}{c}\text { energia } \\
\text { sprężysta } \\
\Phi\left[\mathrm{J} / \mathrm{mm}^{3}\right]\end{array}$ & 240,8 & 305,8 & 428,1 & 513,5 & 606,7 & 734,2 & 873,7 & $1.025,4$ & $1.189,3$ \\
\hline 3 & $\begin{array}{l}\text { wskaźnik } \\
\frac{E}{R_{0,2}}\end{array}$ & 653,9 & 580,2 & 490,4 & 447,8 & 412 & 374,5 & 343,3 & 316,9 & 294,2 \\
\hline 4 & $\begin{array}{c}\text { wskaźnik } \\
\text { wytrzymałości } \\
\frac{R_{0,2} \cdot E}{\gamma} \\
{[\mathrm{N} / \mathrm{mm}]}\end{array}$ & 8,41 & 9,48 & 11,22 & 12,28 & 13,35 & 14,69 & 16,02 & 17,36 & 18,70 \\
\hline
\end{tabular}

Zestawienie energii sprężystej $\Phi$, którą mogą przejąć elementy konstrukcyjne w postaci prętów wykonanych z różnych gatunków stali typu Domex

Tabela 3 
stale typu Domex wykazują wysoką udarność w niskich $\left(-20^{\circ} \mathrm{C}\right)$ oraz bardzo niskich temperaturach ($40^{\circ} \mathrm{C}$ ). Odpowiednie zestawienie wartości udarności dla poszczególnych stali zawarto w tabeli 4.

Granica wytrzymałości na rozciaganie $\mathrm{R}_{\mathrm{m}} \mathrm{i}$ udarności złączy spawanych jest mierzona metodą Charpy'ego
V na próbkach stali formowanych na zimno. Przedstawione złącza wykonane są metodą MAG ( spoina czołowa, mieszanka gazowa, powierzchnia spoiny umocniona w znacznym odstępstwie czasowym przed wykonaniem testu, spoiny czołowe typu $\mathrm{V}$ na próbkach o wymiarach 6 i $8 \mathrm{~mm}$ ) jak również metodą laserowa i plazmowa.

\section{Zestawienie wyników testów udarności dla zlącz spawanych wykonanych metodą: MAG, laserową i plazmową}

Tabela 4

\begin{tabular}{|c|c|c|c|c|c|c|c|c|c|c|c|}
\hline \multirow{3}{*}{$\begin{array}{l}\text { L. } \\
\text { p. }\end{array}$} & \multirow{3}{*}{$\begin{array}{l}\text { Meto- } \\
\text { da } \\
\text { wyko- } \\
\text { nania } \\
\text { spoiny }\end{array}$} & \multirow{3}{*}{$\begin{array}{l}\text { Gatunek } \\
\text { stali } \\
\text { Domex } \\
\text { (grubość } \\
\text { w mm) }\end{array}$} & \multirow{3}{*}{$\begin{array}{l}\text { Elek- } \\
\text { troda }\end{array}$} & \multirow{3}{*}{$\begin{array}{l}\text { Ilość } \\
\text { prze- } \\
\text { jść }\end{array}$} & \multirow{3}{*}{$\begin{array}{c}\text { Ciepło } \\
\text { dopro- } \\
\text { wadzone } \\
{[\mathrm{kJ} / \mathrm{mm}]}\end{array}$} & \multicolumn{3}{|c|}{$\begin{array}{l}\text { Test wytrzymałości w kie- } \\
\text { runku poprzecznym do } \\
\text { spoiny }\end{array}$} & \multicolumn{3}{|c|}{$\begin{array}{l}\text { Test udarności } \\
\text { wg Charpy'go } \\
\text { (Charpy V) }\end{array}$} \\
\hline & & & & & & \multirow[t]{2}{*}{$\begin{array}{c}\mathrm{R}_{\mathrm{m}} \\
{[\mathrm{Mpa}]}\end{array}$} & \multirow[t]{2}{*}{$\begin{array}{l}\text { Miejsce } \\
\text { złama- } \\
\text { nia }\end{array}$} & \multirow[t]{2}{*}{$\begin{array}{l}\text { Kierunek } \\
\text { złamania }\end{array}$} & \multirow[t]{2}{*}{$\begin{array}{c}\text { Poz. } \\
\text { 1) }\end{array}$} & \multicolumn{2}{|c|}{$\begin{array}{l}\text { Energia zde- } \\
\text { rzenia } \\
\mathrm{J} / \mathrm{cm}^{2} \text { przy } \\
\text { temp. }\end{array}$} \\
\hline & & & & & & & & & & $-20^{\circ} \mathrm{C}$ & $-40^{\circ} \mathrm{C}$ \\
\hline 1 & MAG & $\begin{array}{l}\mathrm{Dx} 355 \mathrm{MC} \\
\text { (6) }\end{array}$ & $\begin{array}{l}\text { OK12. } \\
51\end{array}$ & 1 & 0,87 & 476 & $\begin{array}{l}\text { materiał } \\
\text { rodzimy }\end{array}$ & $\begin{array}{l}\text { kierunek } \\
\text { wzdłużny }\end{array}$ & $\begin{array}{l}\text { A } \\
\mathrm{B} \\
\mathrm{C}\end{array}$ & $\begin{array}{l}133 \\
258 \\
270\end{array}$ & $\begin{array}{c}99 \\
250 \\
256\end{array}$ \\
\hline 2 & MAG & $\begin{array}{l}\mathrm{Dx} 500 \mathrm{MC} \\
(6)\end{array}$ & $\begin{array}{l}\text { OK12. } \\
51\end{array}$ & 1 & 1,2 & 595 & $\begin{array}{l}\text { materiał } \\
\text { rodzimy }\end{array}$ & $\begin{array}{l}\text { kierunek } \\
\text { wzdłużny }\end{array}$ & $\begin{array}{l}\mathrm{A} \\
\mathrm{B} \\
\mathrm{C} \\
\end{array}$ & $\begin{array}{l}168 \\
162 \\
256 \\
\end{array}$ & $\begin{array}{l}174 \\
170 \\
244 \\
\end{array}$ \\
\hline 3 & MAG & $\begin{array}{l}\mathrm{Dx} 500 \mathrm{MC} \\
\text { (6) }\end{array}$ & $\begin{array}{l}\text { OK12. } \\
51\end{array}$ & $\begin{array}{l}1 \\
2\end{array}$ & $\begin{array}{l}1,3 \\
1,5\end{array}$ & 636 & $\begin{array}{l}\text { materiał } \\
\text { rodzimy }\end{array}$ & $\begin{array}{l}\text { kierunek } \\
\text { wzdłużny }\end{array}$ & $\begin{array}{l}\text { A } \\
\mathrm{B} \\
\mathrm{C} \\
\end{array}$ & $\begin{array}{r}61 \\
138 \\
275 \\
\end{array}$ & $\begin{array}{c}42 \\
46 \\
120 \\
\end{array}$ \\
\hline 4 & MAG & $\begin{array}{l}\text { Dx650MC } \\
(6) \\
\end{array}$ & $\begin{array}{l}\text { TD- } \\
\text { T90 } \\
\end{array}$ & $\begin{array}{l}1 \\
2 \\
\end{array}$ & $\begin{array}{l}0,73 \\
0,81 \\
\end{array}$ & 810 & $\begin{array}{l}\text { strefa } \\
\text { wpływu } \\
\text { ciepła }\end{array}$ & $\begin{array}{l}\text { kierunek } \\
\text { poprze- } \\
\text { czny } \\
\end{array}$ & $\begin{array}{l}\mathrm{A} \\
\mathrm{B} \\
\mathrm{C} \\
\end{array}$ & & $\begin{array}{c}207 \\
51 \\
107 \\
\end{array}$ \\
\hline 5 & MAG & $\begin{array}{l}\text { Dx650MC } \\
(3)\end{array}$ & SG700 & $\begin{array}{l}1 \\
2 \\
\end{array}$ & $\begin{array}{l}0,61 \\
1,2 \\
\end{array}$ & 774 & $\begin{array}{l}\text { material } \\
\text { spawa- } \\
\text { ny }\end{array}$ & $\begin{array}{l}\text { kierunek } \\
\text { poprze- } \\
\text { czny } \\
\end{array}$ & $\begin{array}{l}\mathrm{A} \\
\mathrm{B} \\
\mathrm{C} \\
\end{array}$ & $\begin{array}{r}176 \\
72 \\
89 \\
\end{array}$ & $\begin{array}{c}172 \\
46 \\
58 \\
\end{array}$ \\
\hline 6 & MAG & $\begin{array}{l}\text { Dx700MC } \\
\text { (3) }\end{array}$ & $\begin{array}{l}\text { OK13. } \\
13\end{array}$ & 1 & 0,29 & 829 & $\begin{array}{l}\text { material } \\
\text { spawa- } \\
\text { ny }\end{array}$ & & & & \\
\hline 7 & MAG & $\begin{array}{l}\text { Dx } 700 M C \\
\text { (3) }\end{array}$ & $\begin{array}{l}\text { OK } 13 . \\
13\end{array}$ & 1 & 0,33 & 846 & $\begin{array}{l}\text { strefa } \\
\text { wpływu } \\
\text { ciepła }\end{array}$ & & & & \\
\hline 8 & MAG & $\begin{array}{l}\text { Dx } 700 \mathrm{MC} \\
(8)\end{array}$ & $\begin{array}{l}\text { OK13. } \\
31\end{array}$ & 1 & $\begin{array}{l}0,73 \\
0,70 \\
0,71 \\
\end{array}$ & 836 & $\begin{array}{l}\text { materiał } \\
\text { rodzimy }\end{array}$ & $\begin{array}{l}\text { kierunek } \\
\text { wzdłużny }\end{array}$ & $\begin{array}{l}\text { A } \\
\text { B } \\
\text { C } \\
\end{array}$ & $\begin{array}{c}71 \\
80 \\
156 \\
\end{array}$ & $\begin{array}{l}52 \\
69 \\
61 \\
\end{array}$ \\
\hline 9 & MAG & $\begin{array}{l}\text { Dx 700MC } \\
(8)\end{array}$ & $\begin{array}{l}\text { OK13. } \\
31\end{array}$ & $\begin{array}{l}1 \\
2 \\
\end{array}$ & $\begin{array}{l}0,96 \\
0,95 \\
\end{array}$ & 849 & $\begin{array}{l}\text { materiał } \\
\text { rodzimy }\end{array}$ & & & & \\
\hline 10 & plazma & $\begin{array}{l}\mathrm{Dx} 355 \mathrm{MC} \\
(8)\end{array}$ & $\begin{array}{l}\text { OK } 12 . \\
51\end{array}$ & 1 & 0,65 & 455 & $\begin{array}{l}\text { materiał } \\
\text { rodzimy }\end{array}$ & & & & \\
\hline 11 & laser & $\begin{array}{l}\mathrm{Dx} 420 \mathrm{MC} \\
(8)\end{array}$ & - & 1 & 0,38 & 539 & $\begin{array}{l}\text { materiał } \\
\text { rodzimy }\end{array}$ & $\begin{array}{l}\text { kierunek } \\
\text { wzdłużny }\end{array}$ & $\begin{array}{l}\text { A } \\
\text { B } \\
\text { C } \\
\end{array}$ & 198 & $\begin{array}{l}117 \\
245 \\
302 \\
\end{array}$ \\
\hline 12 & laser & $\begin{array}{l}\text { Dx } 700 M C \\
\text { (6) }\end{array}$ & - & 1 & 0,25 & 816 & $\begin{array}{l}\text { materiał } \\
\text { rodzimy }\end{array}$ & $\begin{array}{c}\text { kierunek } \\
\text { wzdłużny }\end{array}$ & $\begin{array}{l}\text { A } \\
\text { B } \\
\text { C } \\
\end{array}$ & $\begin{array}{l}208 \\
153 \\
135 \\
\end{array}$ & $\begin{array}{r}83 \\
150 \\
105 \\
\end{array}$ \\
\hline
\end{tabular}

1) $A=$ materiat spawany, $B=$ linia taczenia, $C=$ strefa wplywu ciepla ( ( heat affected zone-HAZ) $1 \mathrm{~mm}$ od linii taczenia 
Jak widać z tabel 2,3 i 4 ww. gatunki stali ze względu na:

- wysoką granicę plastyczności $\mathrm{R}_{0.2}$ oraz wysoką granicę wytrzymałości na rozciaganie $\mathrm{R}_{\mathrm{m}}$

- wysokie wartości udarności w całym potencjalnym eksploatacyjnym zakresie temperaturowym, a zwłaszcza w niskich temperaturach

- dobrą spawalność ( cieplny równoważnik węgla $\mathrm{C}_{\mathrm{E}}<0,42 \%$ )

mogą spełnić kryteria bezpieczeństwa pasywnego zmniejszającego bezpośrednie skutki zderzeń współczesnych konstrukcji pojazdów szynowych jak również jednocześnie spełnić wymagania do przeniesienia sił pionowych dla wagonów towarowych zgodnie $\mathrm{z}$ raportem ORE/ERRI B12/Rp.17 [25] oraz kartą UIC 566 [14].

Użycie ww. stali o podwyższonych własnościach wytrzymałościowych ma już miejsce $\mathrm{w}$ budowie pojazdów szynowych np. w wagonach towarowych ( firma Schwab Verkehrstechnik AG [22]).

\subsection{Inne nowe materiały na elementy konstrukcji nośnych pojazdów}

We współczesnych pojazdach szynowych, którym jest postawione wymaganie minimalnej masy własnej oraz wymaganie pasywnego bezpieczeństwa, zaistniała konieczność poszukiwania materiałów cechujących się minimalna masą właściwą ( mniejszą aniżeli stali, dla której $\rho=7860 \mathrm{~kg} / \mathrm{m}^{3}$ ) i cechujących się bardzo wysokimi parametrami wytrzymałościowymi. Inspiracją do tego było między innymi zastosowanie stopów aluminium $\mathrm{w}$ przemyśle lotniczym, które miało po raz pierwszy miejsce w 1919 roku przez zakłady lotnicze Junkersa [7]. Aluminium jako czysty pierwiastek posiada względnie niską wytrzymałość i bardzo dużą ciągliwość. Przykładem tego może być zdolność do walcowania folii aluminiowych o grubości $5 \mu \mathrm{m}$, które pomimo małych grubości wykazują absolutną odporność na przepuszczanie promieni słonecznych i wykazują szczelność w przypadku oddziaływania gazów oraz pary. W przypadku stopów aluminium, w skład których wchodzą takie pierwiastki jak $\mathrm{Mn}, \mathrm{Mg}, \mathrm{Si}, \mathrm{Zn}$ oraz $\mathrm{Cu}$ wytrzymałość na rozciaganie $\mathrm{R}_{\mathrm{m}}$ można zwiększyć nawet do $800 \mathrm{MPa}$. W związku z powyższym stopy aluminium zostały zastosowane do konstrukcji pudeł wagonowych, zwłaszcza w wagonach osobowych oraz zespołach trakcyjnych przeznaczonych do wysokich prędkości. Najczęściej stosowanymi elementami są profile w kształcie rur o długości $600 \mathrm{~mm}$, stosowane na konstrukcje pudeł wagonów osobowych z pojedynczą lub podwójną ścianką. Konstrukcja ta jest użebrowana wspornikami jako wyrobami walcowanymi o szerokości $130 \mathrm{~mm}$ i o grubości nie mniejszej niż $3 \mathrm{~mm}$. W przypadku zderzenia pojazdów, rury muszą przenieść siły wzdłużne. Jeśli te siły przekroczą nośność konstrukcji, to wówczas nastapią jej trwałe odkształcenia. W przypadku przekro- czenia granicznego stosunku szerokości wspornika do jego grubości, który zależy od granicy plastyczności materiału, wystapi odkształcenie plastyczne, które jest powiązane z możliwością wystąpienia jego wyboczenia. Plastyczna deformacja oznacza rozpraszanie energii, podczas gdy przy sprężystej niestateczności nie może być przejęta praktycznie żadna energia wynikająca ze zderzenia. W przypadku stopów aluminium przejmowanie energii jest naznaczone istotnym postępem. Niezwykle istotnym jest, aby w przypadku deformacji osiagnacé wysokie plastyczne odkształcenie. Przykładami stopów aluminiowych spełniających te wymagania jest stop AlMgSi0,7 o oznaczeniu EN AW 6005 oraz stop będący jego modyfikacją o oznaczeniu EN AW 6008, w którym dodatki stopowe takich pierwiastków jak $\mathrm{Mn}$ i $\mathrm{Cr}$ zostają zastapione przez wanad $(\mathrm{V})$. W wyniku powyższego specjalna obróbka cieplna o oznaczeniu T7 ( wyżarzanie rozpuszczające mające na celu otrzymanie struktury jednofazowej i podhartowanie) pozwala osiagnąc takie stany, które umożliwiają osiagnnięcie $50 \%$ rzeczywistych odkształceń przy lekko zredukowanej granicy plastyczności $\sigma_{0.2}$ do $180 \mathrm{MPa}$. Dlatego jest możliwe, że energia zderzenia jest przejęta w plastycznym zakresie wyboczenia aż do momentu kiedy zostanie osiagnięte pełne „pofałdowanie” elementów konstrukcyjnych. Przy zastosowaniu pojazdów z pudłami aluminiowymi naprawa $\mathrm{w}$ celu dostosowania pojazdu do ponownej eksploatacji jest opłacalna przy zastosowaniu prostowania na zimno lub na gorąco i to tylko przy wystapieniu małych plastycznych deformacji. Naprawy przeprowadza się również poprzez wycięcie uszkodzonych części i zastapienie ich nowymi elementami. Miejsca wycięcia muszą być konsultowane $\mathrm{z}$ konstruktorami tak, aby znajdowały się one tam, gdzie występuja najmniejsze naprężenia $i$ aby spoiny naprawcze znajdowały się w strefach, które nie są narażone na niedopuszczalne wytężenie materiału przy działaniu obciążeń statycznych oraz zmęczeniowych.

3. Nowoczesne konstrukcje pojazdów szynowych spełniające wymagania pasywnego bezpieczeństwa

3.1. Zastosowanie nowych konstrukcji wagonówcystern do przewozów ladunków niebezpiecznych

Odpowiedzią na nowe wymagania dotyczące bezpieczeństwa przed skutkami zderzeń jest nowoczesna konstrukcja wagonu-cysterny do przewozu ładunków niebezpiecznych zwana potocznie CeSa ( skrót nazwy pojazdu szynowego „Chemiekesselwagen für erhöhte Sicherheitsanforderungen” ), wyprodukowanego jako prototyp w dwóch wersjach, o pojemności użytkowej $60 \mathrm{~m}^{3}$ i $70 \mathrm{~m}^{3}$ [20]. Nowa cysterna została wyprodukowana przez firmę Alstom LHB GmbH w Salzgitter w ramach programu badawczo-rozwojowego, wspieranego przez Ministerstwo Oświaty i Rozwoju (BMBF). 
Parametry obydwu odmian wagonu podano w tabeli 5.

\section{Zestawienie parametrów wagonu typu CeSa do przewozu materiałów niebezpiecznych}

Tabela 5

\begin{tabular}{|c|c|c|}
\hline L.p. & Parametr pojazdu & $\begin{array}{c}\text { Wartość parametru } \\
\text { względnie oznacze- } \\
\text { nie }\end{array}$ \\
\hline 1. & $\begin{array}{l}\text { Zarys skrajni } \\
\text { kinematycznej }\end{array}$ & $\begin{array}{c}\text { według karty UIC } \\
505-1[9]\end{array}$ \\
\hline 2. & $\begin{array}{l}\text { Masa własna wagonu o } \\
\text { pojemności użytkowej } \\
\text { ok. } 60 \mathrm{~m}^{3}\end{array}$ & $24300 \mathrm{~kg}$ \\
\hline 3. & $\begin{array}{l}\text { Masa własna wagonu o } \\
\text { pojemności użytkowej } \\
\text { ok. } 70 \mathrm{~m}^{3}\end{array}$ & $25200 \mathrm{~kg}$ \\
\hline 4. & $\begin{array}{l}\text { Typ wózka (układu bie- } \\
\text { gowego) }\end{array}$ & DB 652 (LHB 82) \\
\hline 5. & Typ hamulca & KE-GP-16" \\
\hline 6. & Długość zbiornika $60 \mathrm{~m}^{3}$ & $10960 \mathrm{~mm}$ \\
\hline 7. & Długość zbiornika $70 \mathrm{~m}^{3}$ & $12750 \mathrm{~mm}$ \\
\hline 8. & Średnica zbiornika & $2700 \mathrm{~mm}$ \\
\hline 9. & Materiał na zbiornik & stal nr $1.4571 \mathrm{wg}[19]$ \\
\hline 10. & Ciśnienie obliczeniowe & $10 \mathrm{bar}$ \\
\hline 11. & $\begin{array}{l}\text { Ciśnienie badawcze } \\
\text { (próbne) }\end{array}$ & 4 bar \\
\hline 12. & Ciśnienie eksploatacyine & 3 bar \\
\hline 13. & Ciśnienie zewnetrzne & $0,5 \mathrm{bar}$ \\
\hline
\end{tabular}

Konstrukcja została opracowana na podstawie przeprowadzonej analizy wypadków na sieci kolejowej DB AG, które wystapiły w okresie 1985 1995 .

Największe znaczenie przy opracowaniu nowego projektu miał fakt, że najwięcej wypadków odbyło się przy prędkości nie przekraczającej $10 \mathrm{~m} / \mathrm{s}(36 \mathrm{~km} / \mathrm{h})$. Na podstawie wyników analiz opracowano wymagania, jakie powinna spełniać nowa konstrukcja, które sprowadzają się do:

- zachowania bezpieczeństwa przed skutkami zderzeń przy prędkości do $36 \mathrm{~km} / \mathrm{h}$, co należy osiagnąć przez wysokie przejmowanie energii przez pojazd

- efektywnej ochrony dna zbiornika, ulepszonej ochrony włazu, armatury i urządzeń opróżniających

- zmiany połączenia pomiędzy ostoją wagonu oraz zbiornikiem.

Ze wszystkich zrealizowanych wymagań konstrukcyjnych, które udało się spełnić, można wymienić:

- optymalnie elastyczne podwozie odporne na nabiegania do prędkości $15 \mathrm{~km} / \mathrm{h}$

- urządzenia przejmujące energię przy prędkościach nabiegania do $36 \mathrm{~km} / \mathrm{h}$ przy małych ciśnieniach wewnętrznych, wynoszących 8 bar przy prędkości $40 \mathrm{~km} / \mathrm{h}$

- wysoka możliwość pochłaniania energii przez konstrukcję zbiornika, połączona $\mathrm{z}$ redukcją elementów usztywniających elementy do minimum
- nowy sposób osadzenia zbiornika tzw. sposób ślizgowy

- urządzenia chroniące zbiornik, osadzone z obu jego stron czołowych.

Równolegle do wagonów prototypowych typu CeSa rozpoczęto prace projektowo-wdrożeniowe w zakresie zespołu pochłaniającego energię, w którym dokonano integracji zabudowy zderzaka razem $\mathrm{z}$ elementem pochłaniającym energię przy zderzeniach nadzwyczajnych ( crashelement). Zintegrowane elementy zderzno-pociagowe były rozwijane przez brytyjską firmę Oleo International Ltd wspólnie z biurem projektowym Herbert Hoffmann w Bremen. Element ten może być zabudowany nie tylko w wagonachcysternach, lecz w innych pojazdach szynowych, przy czym na drodze doświadczalno-badawczej dowiedziono jego przydatności do prędkości nabiegania wynoszącej $41,3 \mathrm{~km} / \mathrm{h}$.

Program badawczy prototypowych wagonów-cystern typu CeSa zakładał przeprowadzenie następujących czterech prób doświadczalnych:

1. próbę nabiegania wagonu-cysterny $\mathrm{CeSa}$ o pojemności $60 \mathrm{~m}^{3}$, napełnionej do $95 \%$ woda, z wymaganą prędkością $12 \mathrm{~km} / \mathrm{h}$ ( dopuszczalna prędkość nabiegania przy próbach ) zgodnie z raportem ERRI B12 Rp.17 [25]; dokładna prędkość zmierzona podczas próby wynosiła $13,5 \mathrm{~km} / \mathrm{h}$, natomiast pojazdem nabiegającym ( taranem) był załadowany wagon do przewozu thucznia o masie brutto $80000 \mathrm{~kg}$; osiagnięte przyspieszenie wyniosło $2,5 \mathrm{~g}\left(24,525 \mathrm{~m} / \mathrm{s}^{2}\right)$,

2. próby zderzenia $\mathrm{z}$ wymaganą prędkością 36 $\mathrm{km} / \mathrm{h}$; przy zmierzonej prędkości $35 \mathrm{~km} / \mathrm{h}$ osiagnięto przejętą energię wynoszącą $2 \mathrm{MJ}$; wagon-cysterna wykazał po uderzonej stronie wgłębienie; elementy rozpraszające energię wykazały dwie deformacje w kształcie pofalowań,

3. tradycyjny wagon-cysternę o pojemności użytkowej $88 \mathrm{~m}^{3}$ napełniono wodą do $70 \%$ całkowitej pojemności i wyposażono w dwa elementy przejmujące energię przy zderzeniach nadzwyczajnych oraz wykonano próbę zderzenia przy prędkości $35,4 \mathrm{~km} / \mathrm{h}$; elementy rozpraszające energię wykazały tylko cztery deformacje w kształcie pofalowań; pojazd po wymianie zintegrowanych elementów zderzno-pochłaniających ( tzw. Crashpuffer) w ciagu około jednej godziny był gotowy znów do eksploatacji, co zdaniem firmy Oleo International Ltd jest najlepszym rodzajem ,,przezbrojenia" pojazdu,

4. dwa konwencjonalne stare wagony-cysterny o pojemności użytkowej $77 \mathrm{~m}^{3}$ i wagon-cysternę o pojemności $88 \mathrm{~m}^{3}$, każdy załadowany do masy brutto $80 \mathrm{t}$ zostały przekazane do 
próby niszczącej, eliminującej w praktyce wagony $\mathrm{z}$ dalszej eksploatacji, przy czym prędkość nabiegania wynosiła $36 \mathrm{~km} / \mathrm{h}$; duże zaskoczenie wywołał fakt, że tylko ramy wózków wykazały największe odkształcenia;zmierzone przyspieszenie podczas próby wyniosło $35 \mathrm{~g}\left(343,35 \mathrm{~m} / \mathrm{s}^{2}\right)$.
Przeprowadzone próby potwierdziły łatwość montażu i demontażu nowych zintegrowanych elementów zderzno-pochłaniających. Na rys.1 przedstawiono widok ogólny wagonu-cysterny CeSa. Na rys. 2 przedstawiono układ zderzno-pochłaniający wagonu CeSa przed zderzeniem, natomiast na rys. 3 po zderzeniu. Na rys. 4 przedstawiono element zderzno-pochłaniający zastosowany $\mathrm{w}$ wagonie-cysternie do przewozu chemikaliów.

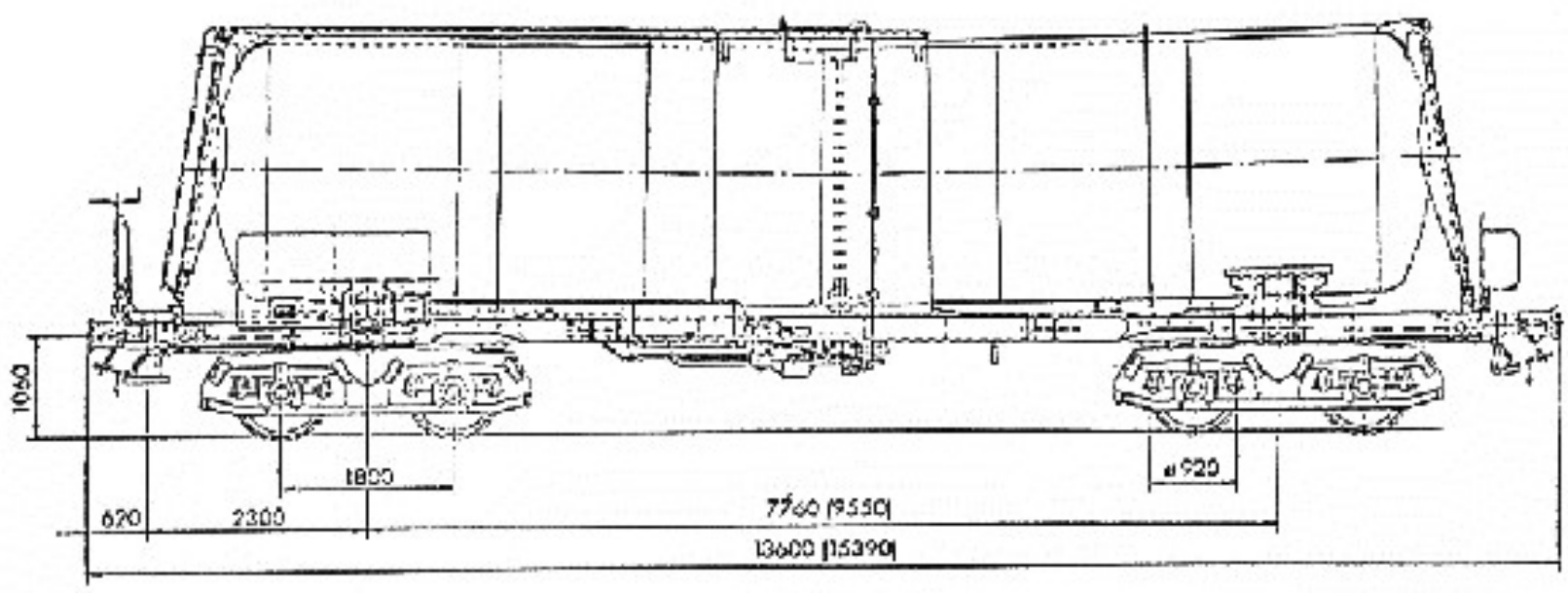

Rys.1. Wagon-cysterna do przewozu chemikaliów typu CeSa ( widok ogólny)

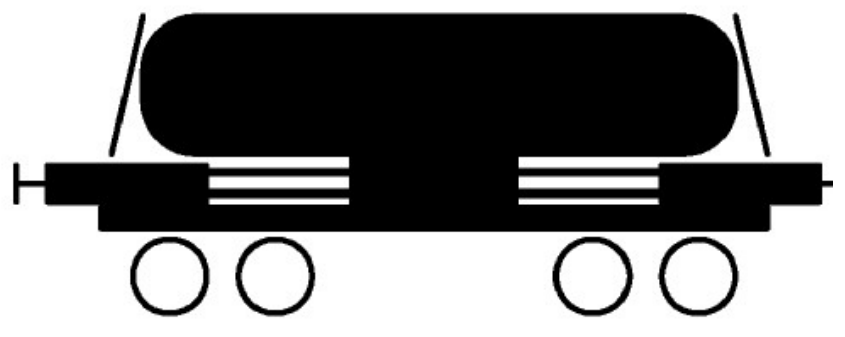

Rys.2. Układ zderzno-pochłaniający wagonu-cysterny typu CeSa do przewozu chemikaliów przed zderzeniem

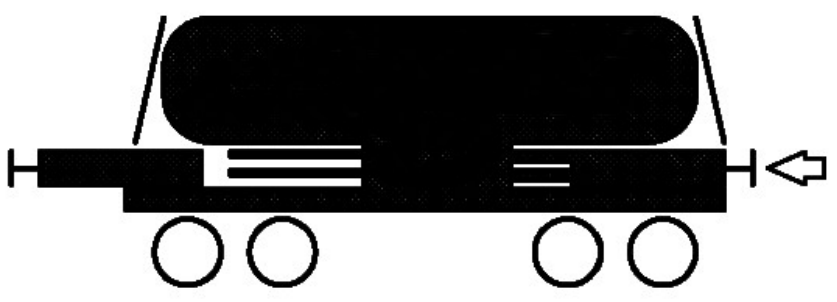

Rys.3. Układ zderzno-pochłaniający wagonu-cysterny typu CeSa do przewozu chemikaliów po zderzeniu
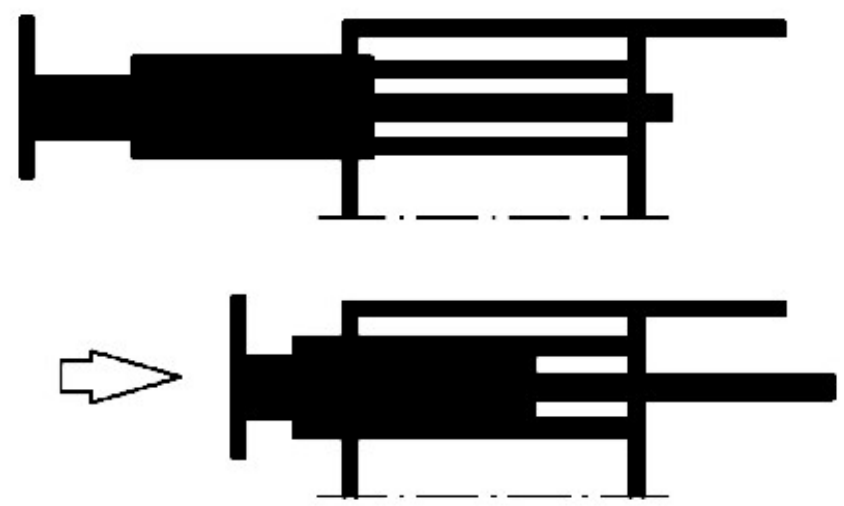

Rys.4. Element zderzno-pochłaniający zastosowany w wagonie-cysternie do przewozu chemikaliów typu $\mathrm{CeSa}$

( przed i po zderzeniu)

\subsection{Przykłady rozwiązań konstrukcyjnych elemen- tów zderzno-pochlaniających (tzw. crash- elemente)}

Przykładem zastosowania nowych elementów zderzno-pochłaniających w pojazdach szynowych są tzw. crashelemente produkowane przez niemiecką firmę EST EisenbahnSystemtechnik $\mathrm{GmbH}$ w Wangen [21]. Cechami nowych konstrukcji tego typu, obok własności umożliwiających regularną eksploatację, są między innymi: 
- standardowy zderzak i element deformacyjny, zintegrowany konstrukcyjnie, tworząc jeden zespół

- miejsce zabudowy oraz kołnierz ( pokrywa do zabudowy) są takie same jak w zderzakach standardowych

- możliwość zabudowy elementów w wagonach towarowych ,G1” oraz w wagonach osobowych ,R1"

- wkład elastomerowy zderzaka spełniający wymagania według karty UIC 526-1[10] względnie według karty UIC 528 [12]

- bardzo mała masa własna $125 \mathrm{~kg}$ ( przypadająca na jeden element zderzno- pochłaniający )

- konstrukcja korpusu elementów umożliwiająca odkształcenie wynoszące ok. 200 mm w przypadku kolizji pojazdów szynowych

- wersja standardowa umożliwiająca przejęcie siły wynoszącej $1500 \mathrm{kN}$ przypadającej na jeden element zderzny ( zderzak) i zdolność przejmowania energii około 600 $\mathrm{kJ}$ na końcu pojazdu/parę zderzaków i w zależności od różnych wersji wykonawczych możliwość przejęcia siły w zakresie $1500 \div 2000 \mathrm{kN}$ na zderzak oraz zdolność przejmowania energii przy odkształceniach od około 400 do $700 \mathrm{~kJ}$, przypadającej na jeden koniec pojazdu ( parę zderzaków).
Elementy zderzno-pochłaniające realizują przejmowanie energii poprzez odkształcenie za pomocą zwijania (aufrollen), zamiast w dotychczasowej formie za pomoca sfałdowania (falten). Wszystkie ww. własności zostały potwierdzone poprzez próby wstępne na stanowiskach badawczych na Wyższej Szkole Inżynierskiej w Koblenz oraz podczas prób nabiegania, przeprowadzonych w ośrodku badawczym w Railmotive Görlitz.

$>$ Następnym przykładem praktycznego rozwiązania jest kombinowana konstrukcja zderzaka i elementu odkształcalnego, przeznaczonego do lokomotyw oraz do wagonów towarowych, pokazana na rys.5.

Opis konstrukcji jest przedstawiony w [5]. Przy konstrukcji elementów tego typu wychodzi się $\mathrm{Z}$ założenia, że zasadniczą wadą zderzaka standardowego jest względnie mała aktywna długość odkształcenia sprężystego wynosząca $105 \mathrm{~mm}$ w stosunku do całkowitej długości $620 \mathrm{~mm}$. Istotą rozwoju nowego elementu przejmującego energię było wykorzystanie pozostałych do dyspozycji 500 $\mathrm{mm}$. Wymagania, które postawiono nowemu elementowi zderzno-pochłaniającemu są przedstawione w tabeli 6.

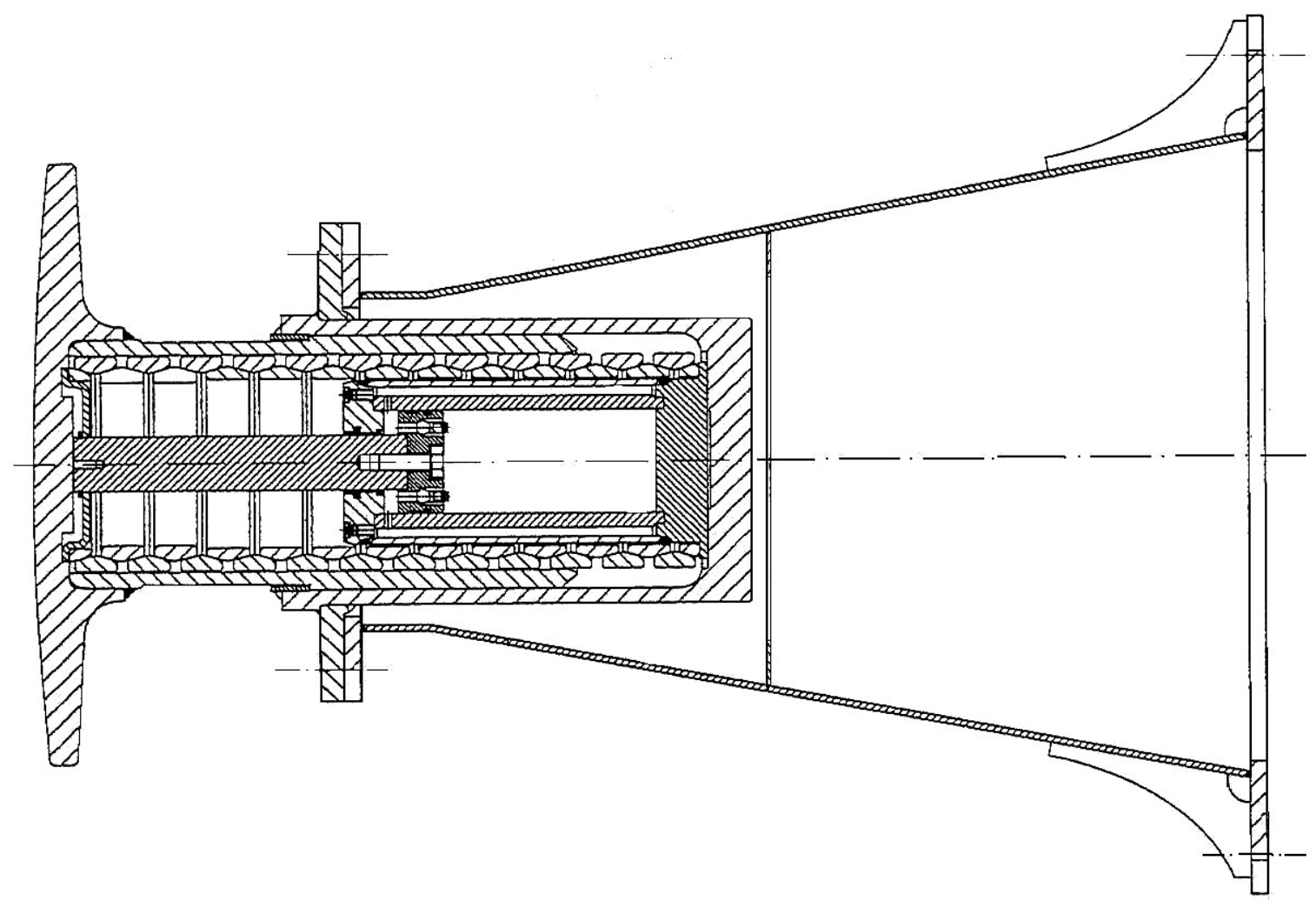

Rys.5. Kombinowana konstrukcja zespołu do wagonów towarowych oraz lokomotyw 


\section{Zestawienie wymagań dotyczących elementów zderzno-pochłaniających dla kombinowanej}

konstrukcji zespołu

Tabela 6

\begin{tabular}{|c|c|c|c|}
\hline L.p. & Element zespołu & Własność-Cecha & Wymaganie \\
\hline \multirow[t]{3}{*}{1.} & \multirow[t]{3}{*}{ Zderzak } & a) Tłumik hydrauliczny & $\begin{array}{l}\text { Wkład sprężysty+ kapsuła hydrauliczna. } \\
\text { Zderzak klasy C o możliwości przejmowa- } \\
\text { nia energii } 70 \mathrm{~kJ} \text {. Mała zależność poziomu } \\
\text { siły od prędkości, odporność na działanie } \\
\text { w niskich temperaturach }\end{array}$ \\
\hline & & b) Typ korpusu & $\begin{array}{l}\text { Korpus tak ukształtowany i posiadający } \\
\text { takie wymiary, że zderzak po wypadku } \\
\text { pozostaje dalej w pełnej gotowości do } \\
\text { pełnienia funkcji. Projekt według karty } \\
\text { UIC 526-1 }[10]\end{array}$ \\
\hline & & c) Materiał & $\begin{array}{l}\text { Z przyczyn cenowo-kosztowych stal St52- } \\
3 \text { (S355J2) }\end{array}$ \\
\hline \multirow[t]{9}{*}{2.} & \multirow[t]{9}{*}{ Element pochłaniający } & a) Przejmowanie energii & Min. $1 \mathrm{MJ}$ ( na pare) \\
\hline & & $\begin{array}{l}\text { b) Średnia siła podczas } \\
\text { deformacji }\end{array}$ & Znacznie poniżej 2000 kN ( na parę) \\
\hline & & $\begin{array}{l}\text { c) Maksymalna siła na } \\
\text { początku deformacji }\end{array}$ & $\begin{array}{l}\text { Nie przekraczająca } 2400 \mathrm{kN} \text { ( na pare) } \\
\text { Wskutek tak względnie małego poziomu } \\
\text { siły nie są konieczne w konstrukcji pojazdu } \\
\text { żadne rezerwy wymiarowe. Oprócz tego } \\
\text { powinna być zagwarantowana dobra kom- } \\
\text { patybilność z różnymi rodzajami pojaz- } \\
\text { dów, które mogą podlegać zjawiskom } \\
\text { zderzenia. Zależnie od masy pojazdu } \\
\text { otrzymuje się określoną, z reguły bardzo } \\
\text { małą wartość maksymalną dla opóźnienia } \\
\text { podczas zderzenia }\end{array}$ \\
\hline & & $\begin{array}{l}\text { d) Wielkość deformacji } \\
\text { (odkształcenia) }\end{array}$ & Możliwie duża ok. $600 \mathrm{~mm}$ \\
\hline & & $\begin{array}{l}\text { e) Mechanizm } \\
\text { pochłaniający energię }\end{array}$ & $\begin{array}{l}\text { Stabilny z możliwością odtworzenia kształ- } \\
\text { tu przez np. fałdowanie, mała zależność } \\
\text { poziomu siły od prędkości }\end{array}$ \\
\hline & & f) Zakres siłowy & 2000 do $2400 \mathrm{kN}$ \\
\hline & & $\begin{array}{l}\text { g) Zakres przebiegu siły } \\
\text { podczas odkształcenia }\end{array}$ & $\begin{array}{l}\text { Oscylujący poziom siły z powodu zmiany } \\
\text { kształtu przez fałdowanie }\end{array}$ \\
\hline & & h) Materiał & \begin{tabular}{|ll} 
Ze względów kosztowo-cenowych stal \\
St52-3( S355J2)
\end{tabular} \\
\hline & & i) Mocowanie & $\begin{array}{l}\text { Mocowanie za pomoca śrub pomiędzy } \\
\text { zderzakiem i elementem pochłaniającym } \\
\text { konstrukcją pojazdu, aby zapewnić możli- } \\
\text { wość szybkiej wymiany }\end{array}$ \\
\hline \multirow[t]{3}{*}{3.} & \multirow[t]{3}{*}{ Cały zespół } & a) Długość zabudowy & $\begin{array}{l}1100 \mathrm{~mm} \text {, kołnierz w jednej płaszczyźnie } \mathrm{z} \\
\text { kołnierzem urządzenia pociagowo- } \\
\text { zderznego }\end{array}$ \\
\hline & & $\begin{array}{l}\text { b) Koszty LCC (Life } \\
\text { Cycle Costs) } \\
\end{array}$ & Możliwie minimalne \\
\hline & & c) Masa & Możliwie minimalna \\
\hline
\end{tabular}

Realizacja programu badawczego odbywała się przez następujących partnerów:

- zespół hydrauliczny zderzaka projektowala grupa z firmy Keystone w Halberstadt

- obliczenia wytrzymałościowe za pomocą metody elementów skończonych-NS Materieel w Utrechcie
- opracowanie koncepcji i konstrukcji założeniowej elementu zderzno-pochłaniającego- prof. Wierzbicki (M.I.T Cambridge) i prof. Abramowicz ( Uniwersytet Warszawski)

- próby dynamiczne- Impact Research Centre na Uniwersytecie Technicznym w Liverpoolu 
- obliczenia i optymalizację zachowania się podczas „fałdowania" przeprowadzono w ścisłej współpracy $\mathrm{z}$ przedsiębiorstwem Industrieanlagen Betriebsgesellschaft mbH IABG w Ottobrunn

- odpowiedzialność za konstrukcję i przygotowanie elementów zderzno-pochłaniających jak również koordynację całościową tematu i prowadzenie programu badawczego-firma Krauss-Maffei Verkehrstechnik GmbH w Monachium.

Dane charakterystyczne zderzaka są następujące:

- kategoria zderzaka C zgodnie z kartą UIC 526-1 [10]

- własności statyczne zgodne z kartą UIC 827-2 [17]

- skok zderzaka105-5 mm

- końcowa siła quasistatyczna $600 \mathrm{kN}$

- przejęta energia statyczna $32 \mathrm{~kJ}$

- quasistatyczny współczynnik tłumienia $68 \%$

- przejęta energia dynamiczna $>70 \mathrm{~kJ}$ (do $12 \mathrm{~km} / \mathrm{h}$ ) oraz $>100 \mathrm{~kJ}$ (przy osiagnnięciu siły końcowej $1500 \mathrm{kN}$ )

- dynamiczny współczynnik thumienia 89\%

- masa zderzaka $215 \mathrm{~kg}$.

Dane charakterystyczne elementu pochłaniającego:

- przejęta energia $>1 \mathrm{MJ}$ ( przypadająca na parę)

- poziom przejętej siły 2000 do $2400 \mathrm{kN}$ ( przypadającej na parę)

- maksymalna siła podczas deformacji (odkształcenia) około 1800 kN ( przypadająca na parę)

- długość deformacji $>600 \mathrm{~mm}$

- wymagania konstrukcyjne w oparciu o raporty ORE/ERRI: ERRI B205/Rp.1 [26], ERRI B 106/Rp.20 [27] i ERRI B106/Rp. 26 [28]

- maksymalna prędkość zderzenia $40 \mathrm{~km} / \mathrm{h}$ (masa brutto $86 \mathrm{t}$ dla obydwu zderzaków kategorii C)

- długość swobodna dla zabudowy $825 \mathrm{~mm}$

- mocowanie zderzaka za pomocą śrub M24, natomiast elementu na pudle lokomotywy za pomocą śrub M30

- masa: $101 \mathrm{~kg}$.

Kolejną konstrukcją, która spełnia wymagania nowoczesnych trendów rozwojowych w tym zakresie jest nowy zderzak szwajcarskiej firmy Schwab Verkehrstechnik AG w Schaffhausen [22]. Firma ta opracowała nowy zderzak posiadający skok $350 \mathrm{~mm}$ i możliwość przenoszenia maksymalnej siły o wartości
2000 kN. Zderzak posiada możliwość przenoszenia siły o wartości ponad $500 \mathrm{kN} \mathrm{w}$ zakresie odkształceń sprężystych. Nowy zderzak odznacza się $z$ jednej strony relatywnie sztywną statyczną charakterystyką o skoku $150 \mathrm{~mm}$ zgodnie z kartą UIC 526-3 [11] lub o skoku $105 \mathrm{~mm}$ zgodnie $\mathrm{z}$ kartą UIC 526-1[10], co gwarantuje bardzo dobrą dynamikę wzdłużną pociagu. $\mathrm{Z}$ drugiej strony dynamiczne własności zderzaka pozwalają na znaczne zmniejszenie występujących przyspieszeń pojazdu, przy czym można to zrealizować przy skoku $350 \mathrm{~mm}$.

> Kolejnym przykładem zastosowania nowego elementu zderzno-pochłaniającego jest lokomotywa typu TRAXX produkcji Bombardier Transportation produkowana dla DB AG i dostarczana do eksploatacji od stycznia 2005 [1]. Dla lepszego rozróżnienia nowa lokomotywa otrzymała nazwę BR185.2, jako wynik modernizacji lokomotywy BR185.1. Modernizacja polegała między innymi na dostosowaniu lokomotywy do wymagań współczesnych przepisów dotyczących bezpieczeństwa przed skutkami zderzeń. W celu wybrania optymalnego rozwiązania $w$ zakresie urządzeń zderzno-pochłaniających uruchomiono dwa wewnętrzne projekty badawcze "MODULA" oraz „OCTEON”. W wyniku przeprowadzonych analiz wybrano ostatecznie kombinowany element DUPLEX G1.A.1, składający się z dwóch zespołów tzn. zespołu zderzaka ( pełniącego funkcję zderzaka oraz elementu pochłaniającego energię typu „Crash”oznaczenie G1-przystosowanego do odkształceń sprężystych oraz trwałych-z języka niemieckiego ,reversible und irreversible Stufe” ) oraz zespołu pochłaniającego A1 ( konsola zderzaka zdolna do przejmowania energii, dodatkowy stopień odkształceń trwałych). Element ten wykazał się najlepszym współczynnikiem wyrażonym jako stosunek wysokiej zdolności przejmowania energii i relatywnie niskiej masy własnej.

Dane charakterystyczne elementu zderznopochłaniającego przedstawiają się następująco:

- całkowita długość zabudowy $1100 \mathrm{~mm}$

- droga deformacji około $700 \mathrm{~mm}$

- głębokość wprowadzenia do czołownicy 0 ......170 mm

- możliwość przejmowania energii 1,7 MJ przypadającej na koniec wagonu

- masa własna $280 \mathrm{~kg}$.

Konstrukcję nowych elementów zderznopochłaniających podjęli również producenci krajowi np. Fabryka Urządzeń Mechanicznych 


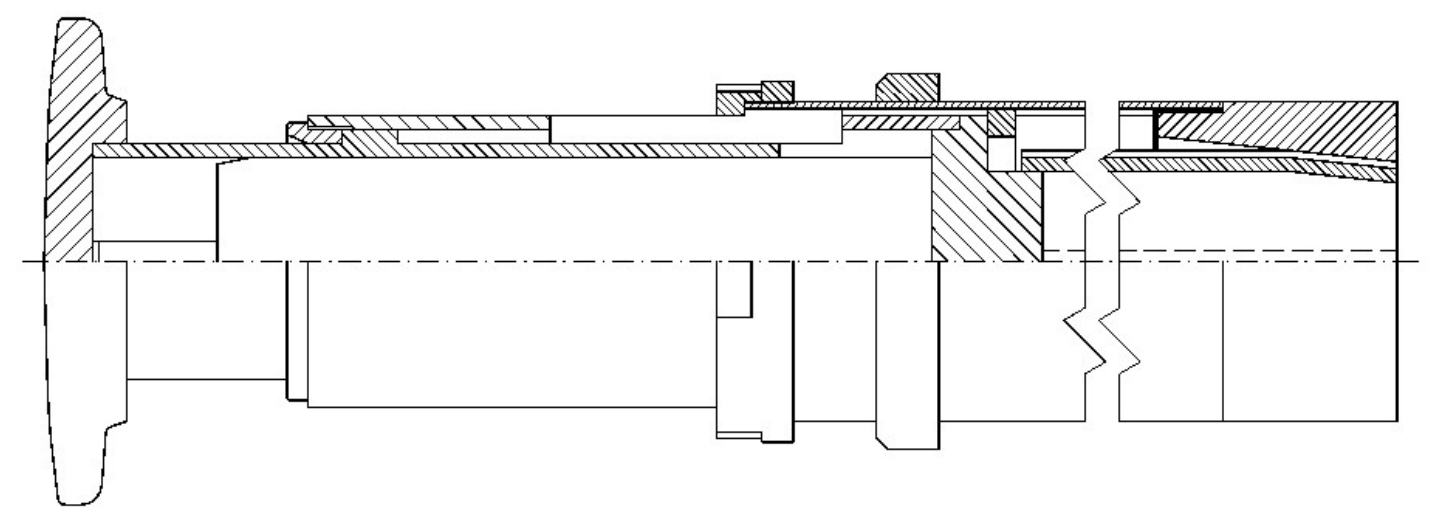

Rys.6. Zderzak dwustopniowy produkowany przez Fabrykę Urządzeń Mechanicznych KAMAX S.A. w Kańczudze

KAMAX S.A. w Kańczudze (rys.6) Zderzak dwustopniowy jest zbudowany na bazie zderzaka KX-ZC4 ( kategoria C ) i jest wyposażony w element typu CRASH. Dane charakterystyczne elementu zderzno-pochłaniającego przedstawiają się następująco:

- zdolność do przejmowana energii $>0,4$ MJ

- poziom siły wyzwalającej element CRASH $1500 \mathrm{kN}$

- ugięcie ( całkowita deformacja) $510 \mathrm{~mm}$, z czego na zderzak przypada $105 \mathrm{~mm}$ natomiast na element CRASH $400 \mathrm{~mm}$.

Zderzaki można stosować w wagonach nowobudowanych oraz $\mathrm{w}$ wagonach już eksploatowanych. Poziom siły wyzwalającej i siły deformacji, a więc i energii przejętej może być zmieniany $\mathrm{w}$ pewnych granicach zgodnie $\mathrm{z}$ wymaganiami klienta.

> Przykładem zastosowania nowego elementu zderzno-pochłaniającego jest konstrukcja firmy Alstom pokazana na rys.7. Całkowita deformacja plastyczna wynosi $350 \mathrm{~mm}$ osiagnięta przy prędkości $41.3 \mathrm{~km} / \mathrm{h}$.

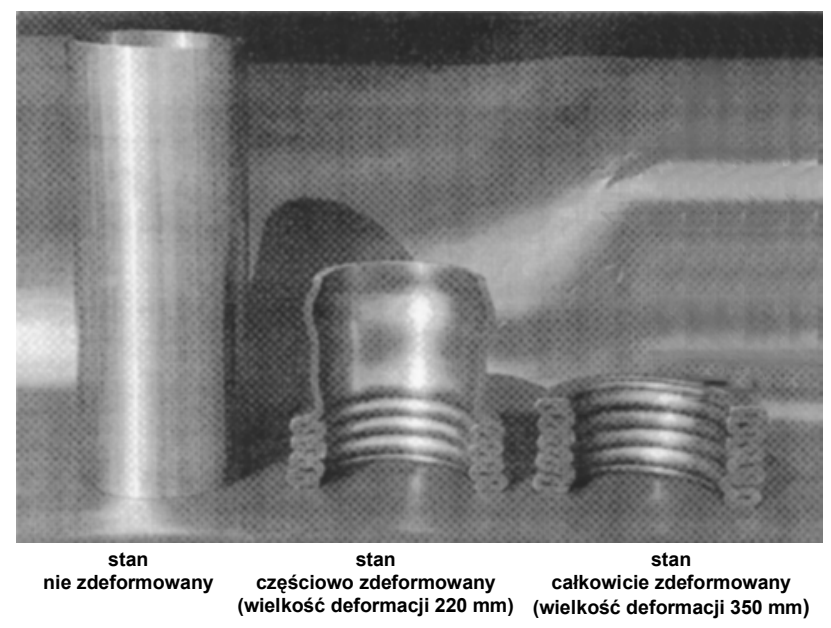

Rys.7. Element przejmujący energię zderzenia konstrukcji firmy Alstom

\section{Podsumowanie}

Jak wynika z przedstawionych przykładów dotyczących zwiększenia ,pasywnego bezpieczeństwa” pojazdów szynowych przed skutkami zderzeń, ich nowoczesne konstrukcje spełniają najnowsze wymagania $\mathrm{w}$ tym zakresie. Jest to wynik istotnego postępu w zakresie inżynierii materiałowej oraz nowoczesnych metod konstruowania i obliczeń przy wykorzystaniu techniki wspomagania komputerowego. W artykule przedstawiono tylko wybrane konstrukcje, wprowadzone już do produkcji seryjnej np. elementy zderznopochłaniające, przeznaczone dla wagonów-cystern, spełniających przepisy karty UIC 573 [15]. Istotny postęp w zakresie przejmowania energii zderzenia można osiągnąć przez zastosowanie nowoczesnych materiałów o wysokiej granicy plastyczności $\mathrm{R}_{0.2}$ oraz dużej ciagliwości $\varepsilon$ ( względnemu wydłużeniu), przy zachowaniu jednak dobrej spawalności ( zwłaszcza w przypadku stali). Bezpieczeństwo pasywne pojazdu szynowego, jako pojęcie stale rozwijające się, będzie w przyszłości definiowane przez coraz bardziej zwiększające się wymagania, którym muszą sprostać konstrukcje pojazdów szynowych i przejąć zwiększającą się energię zderzenia. Istniejące i wprowadzane do kart UIC nowe przepisy dotyczące budowy pojazdów szynowych będę podstawą do konstruowania elementów zderzno-pochłaniających. Istotnym czynnikiem skuteczności zwiększania pasywnego bezpieczeństwa pojazdów szynowych jest aspekt ekonomiczny, czyli koszty pojazdów szynowych spełniających nowe przepisy. Wskutek zwiększającej się konkurencji na rynku transportowym wprowadzanie nowych rozwiązań nie może być związane z gwałtownym zwiększeniem cen nowych pojazdów szynowych. 


\section{Literatura}

[1] Löber M., Schneider S., Sifri N., Trotsch P.: Innovative crashfähige Kastenstruktur der Traxx-Lokomotiven. Elektrische Bahnen 89/2004.

[2] Pietrzyk W.: Polqczenia w konstrukcji maszyn. Politechnika Poznańska. Poznań 1978.

[3] Sanecki H.: Metodyka przygotowania pojazdów testowych do wysokoenergetycznych badań zderzeniowych kabin pojazdów szynowych. Zeszyty Naukowe Instytutu Pojazdów. Wydziat Samochodów i Maszyn Roboczych. Politechnika Warszawska. Nr 2(61)/2006.

[4] Schmidt M.: Moderne FahrwerksrahmenFertigung in Graz. ZEV+DET Glasers Annalen Nr.123.09.1999.

[5] Schneider S., Staub J.: Kombiniertes Pufferund Deformationselement für Schienenfahrzeuge. $Z E V+D E T$ Glasers Annalen $\mathrm{Nr}$. $124,07.2000$.

[6] Wolter W.: Kollisionssichere Eisenbahnfahrzeuge. Eisenbahnfahrzeugbau. Schlussfolgerungen und Empfehlungen. Schienen der Welt, 05.2003.

[7] Zehnder J.: Über die Crash-Sicherheit von Aluminium-Wagenkästen. ZEV+DET Glasers Annalen Nr.125, 9/10 2001.

[8] Karta UIC 432: Wagony towarowe. Prędkości jazdy. Warunki techniczne, które należy spetnić.10-te wydanie, sierpień 2005.

[9] Karta UIC 505-1: Pojazdy kolejowe. Skrajnia pojazdów. 10-te wydanie z maja 2006.

[10] Karta UIC 526-1: Wagony towarowe. Zderzaki o skoku $105 \mathrm{~mm}$. 2-gie wydanie z 1.07.1998.

[11] Karta 526-3. Wagony towarowe. Zderzaki o skoku 130 i $150 \mathrm{~mm}$. 2-gie wydanie $z$ 1.07.1998.

[12] Karta UIC 528: Urzadzenia zderzakowe do wagonów pasażerskich. 7-me wydanie $z$ 1.01.1991 ze zmianq z 1.07.1995.

[13] Karta UIC 529: Wagony towarowe. Amortyzatory hydrodynamiczne o dużym skoku. Warunki techniczne.1-sze wydanie $z$ 01.01.1978.

[14] Karta UIC 566: Obciażenie pudet wagonów pasażerskich i ich części dobudowanych. 3-cie wydanie $z \quad 1.01 .1990 \quad z$ uzupetnieniem $z$ 1.07.1994.

[15] Karta UIC 573: Warunki techniczne dotyczace budowy wagonów-cystern. 6-te wydanie, kwiecień 2005.

[16] Karta UIC 660: Przepisy dotyczace zapewnienia kompatybilności technicznej dla pociqgów do stosowania dużych prędkości. 2-gie wydanie z 08. 2002.
[17] Karta UIC 827-2:Warunki techniczne na dostawe pierścieni stalowych sprężyn zderzakowych. 3 -cie wydanie z 1.01.1981 z uzupetnieniem z 1.04.1981.

[18] PN-EN 10025-2:2005(U): Wyroby walcowane na gorqco ze stali konstrukcyjnych-czesść 2:Warunki techniczne dostawy dla stali konstrukcyjnych niestopowych.

[19] PN-EN 10088-1:2005(U): Stale odporne na korozję. Część 1: Wykaz stali odpornych na korozje.

[20] Alstom GmbH: Präsentation eines SicherheitsChemiekesselwagens CeSa mit Crashversuchen. ZEV+DET Glasers Annalen Nr.124/ 07.2000

[21] EST Eisenbahnsystemtechnik GmbH \&Co.KG: Crashpuffer. ZEV+DET. Glasers Annalen Nr. 126/10.2002.

[22] Schwab Verkehrstechnik AG ( SchaffhausenSchweiz): Neue Puffer. Eisenbahntechnische Rundschau. 1/2005.

[23] Materiat reklamowy: Domex. Welding of cold forming steels. SSAB Tunnplàt AB.2001.

[24] Materiat reklamowy: High strength steels for higher payload on railway wagons. SSAB Tunnplàt AB. SSAB News nr 1 z 2001.

[25] Raport końcowy ERRI B12/ Rp.17 (8-me wydanie): Program prób wagonów towarowych $z$ podwoziem i strukturq wagonu ze stali (które nadaja się do zabudowy automatycznego sprzęu pracujacego na rozciaganie $i$ na ściskanie) i których wózki maja ramę stalowq.

(Versuchsprogramm für Güterwagen mit Untergestell und Wagenkasten aus Stahl (die für den Einbau der Automatischen Zug-Druck Kupplung geeignet sind) und deren Drehgestelle mit stählernem Drehgestellrahmen). Utrecht, kwiecień 1997.

[26] Raport ORE/ERRI B205/Rp.1: Podstawowe wytyczne bezpieczeństwa przed zderzeniem pojazdów szynowych (Leitende Grundsätze der Aufprallsicherheit von Eisenbahnfahrzeugen). Utrecht 11/1994.

[27] Raport ORE/ERRI B106/Rp.20: Wytrzymałość na zderzenia pudta wagonu osobowego. Oddziaływania zderzeń zdeterminowanych wypadkiem na wagony osobowe. Zalecenia warunków technicznych dostawy. ( Stossfestigkeit des Wagenkastens von Reisezugwagen. Auswirkungen unfallbedingter Stösse auf Untersuchung. Vorschläge für technische Lieferbedingungen ). Utrecht 12/1993

[28] Raport ORE/ERRI B106/Rp.26: Numeryczna (dwuwymiarowa) symulacja zderzenia dwóch pociagów pasażerskich z porównaniem dwóch układów konstrukcyjnych. Utrecht 1994. 